Egypt. J. of Appl. Sci., 35 (12) 2020

\title{
EFFECT OF SUCROSE SUBSTITUTION WITH JAGGERY SUGAR ON THE PHYSICOCHEMICAL PROPERTIES OF CAKE
}

\author{
Hashem, M.A.A.M. ${ }^{* 1}$; M. F. Abdel-Aziz ${ }^{1}$; S. A. Soliman ${ }^{2}$
} and Sakina R. Abazied ${ }^{3}$

1-Regional Center for Food \& Feed, Agric. Res. Center, Giza, Egypt.

2-Food Technology Research Institute, Agric. Res. Center, Giza, Egypt.

3-Sugar Crops Research Institute, Agric. Res. Center, Giza, Egypt.

\author{
*Corresponding Author Email: \\ mahmoud5000@gmail.com
}

(02) 01005117017

Key Words: Jaggery _ Sugar _ Cake _ Rheological characteristics _ Storage studies.

\begin{abstract}
:
Jaggery (Gur) is a natural sweetener made by the concentration of sugarcane juice, contains all minerals and vitamins present in sugarcane juice. To utilize jaggery in place of sugar, the cake was prepared by replacing sugar (sucrose) with 20,40,60,80, and $100 \%$ jaggery and the physical and storage properties of the resultant cakes were compared. The results showed that cake prepared with $100 \%$ of jaggery had acceptable quality characteristics. The effect of jaggery in comparison with sugar on the pasting characteristics and physical-sensory storage characteristics of cakes were studied. The cake with Jaggery had a lower overall quality score than the cake with sugar. Even though the cake with Jaggery was less soft, showed a lower overall quality score than the cake with sugar, the cake with Jaggery was acceptable and the cake samples were found to be microbiologically safe, as shown by the microbial load (E. coli and Salmonella. spp.). Hence, it can be concluded that it is possible to replace sugar with jaggery in cakes without affecting the properties of the product.

\section{INTRODUCTION:}

Sugar is an essential ingredient in many foods including bakery products such as cakes and biscuits. In such products, sugar provides sweetness, contributes to the texture, flavor, and color (Manley, 2011). Sucrose is one of the main ingredients in sweet based bakery products. A decrease in the sugar content is accompanied by significant changes in the processing properties of batter/dough, product texture, color, taste and shelf life (De Souza et al. 2013). In bakery products such as cookies and cakes, sugar is one of the main components, contributing up to $30-40 \%$ of the total recipe. Due to increasing health concerns associated with excessive caloric intake and the availability of energy-dense foods, intense scientific research is performed regarding the
\end{abstract}


replacement of sugars with more healthy alternatives (Van Der Sman and Renzetti, 2018).

Manjare and Hole (2016). Reported that Jaggery is an eco-friendly sweetener. The important traditional sweetener is commonly known as Gur in India, Desi in Pakistan, Panela in South America, and Jaggery in African countries.

Scientific research has been confirming that Non-centrifugal sugar (NCS) has multiple health effects. The highest frequency is immunological effects (26\%), followed by anti-toxicity and cytoprotective effects (22\%), anticarcinogenic effects (15\%), and diabetes and hypertension effects (11\%). Some of these effects can be traced to the presence of $\mathrm{Fe}$ and $\mathrm{Cr}$, and others are suggested to be caused by antioxidants (Jaffe, 2012). NCS has nutritionally and functionally significant quantities of minerals, vitamins, and phenolics, among other constituents, as well as antioxidant capacities. (Jaffe, 2015).

As shown in Table (1), Panela or Jaggery (Gur) is a natural sweetener made by the concentration of sugarcane juice, contains all minerals and vitamins present in sugarcane juice, and therefore, it is expected that its nutritional value is higher than that of refined sugar (Kumar and Tiwari, 2006 and Lamdande, et al., 2018). It has been shown that panela has medicinal properties, for example, preventing lung lesions induced by smoke, due to its antioxygenic and anticarcinogenic properties (Sahu and Paul, 1998; Sahu and Saxena, 1994). In addition, it has a potential antioxidant activity owing to the presence of polyphenolic compounds in cane juice (Harish et al., 2009).

Table (1) Effect of consumption $50 \mathrm{~g}$ of refined sugar or Noncentrifugal cane sugar (NCS) on USA Reference Daily Intake (RDI) of minerals and vitamins*.

\begin{tabular}{|c|c|c|c|c|}
\hline \multirow{2}{*}{\multicolumn{2}{|c|}{ Components }} & \multirow{2}{*}{$\begin{array}{c}\text { Reference Daily } \\
\text { Intake } \\
\text { (RDI) }\end{array}$} & $\begin{array}{c}\text { Granulated } \\
\text { (refined) sugar }\end{array}$ & $\begin{array}{l}\text { Non-centrifugal } \\
\text { cane sugar NCS }\end{array}$ \\
\hline & & & \% of RDI & \% of RDI \\
\hline \multirow{13}{*}{ 苞 } & Calcium, mg & $\overline{1000}$ & 0.05 & 5.35 \\
\hline & Chloride, mg & 3400 & 0.00 & 1.84 \\
\hline & Chromium, $\mu \mathrm{g}$ & 120 & 0.00 & 5.81 \\
\hline & Copper, mg & 2 & 0.00 & 36.82 \\
\hline & Todine, $\mu \mathrm{g}$ & 150 & 0.00 & 0.00 \\
\hline & Tron, mg & 18 & 0.14 & 14.04 \\
\hline & Magnesium, mg & 400 & 0.00 & 8.19 \\
\hline & Manganese, mg & 2 & 0.00 & 19.88 \\
\hline & Phosphorus, mg & 1000 & 0.00 & 2.94 \\
\hline & Potassium, mg & 3500 & $\mathbf{0 . 0 3}$ & 7.83 \\
\hline & Selenium, $\mu \mathrm{g}$ & 70 & 0.00 & 0.00 \\
\hline & Sodium, mg & 2400 & 0.02 & 0.77 \\
\hline & Zinc, mg & 15 & 0.03 & 2.16 \\
\hline \multirow{10}{*}{ } & Folate, $\mu \mathrm{g}$ & $\overline{400}$ & 0.00 & 0.63 \\
\hline & Niacin, mg & 20 & 0.00 & 6.27 \\
\hline & Pantothenic acid, mg & 10 & 0.00 & 3.48 \\
\hline & Riboflavin, mg & 1.7 & 0.56 & 1.82 \\
\hline & Thiamin, mg & 1.5 & 0.00 & 1.03 \\
\hline & Vitamin A IU & 5000 & 0.00 & 0.00 \\
\hline & Vitamin B12, $\mu \mathrm{g}$ & 6 & 0.00 & 0.00 \\
\hline & Vitamin B6, mg & 2 & 0.00 & 6.44 \\
\hline & Vitamin C, mg & 60 & 0.00 & 3.83 \\
\hline & Vitamin $\mathrm{K}, \mu \mathrm{g}$ & 80 & 0.00 & 0.00 \\
\hline
\end{tabular}

* References: FDA (2008), USDA (2014), Cited from W.R. Jaffe' / Journal of Food Composition and Analysis 43 (2015) 194-202 197. 
As shown in Table (2), the interest in polyphenols, including flavonoids and phenolic acids, has considerably increased in recent years because of their possible role in the prevention of oxidative stress induced diseases such as cardiovascular complications, diabetes, ulcers and cancer (Halliwell, 2007).

Table (2) List of phenolics detected in NCS (number of reports).

\begin{tabular}{|c|c|c|}
\hline & Name & References \\
\hline \multirow{15}{*}{ 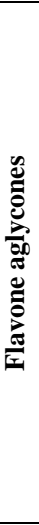 } & $\begin{array}{l}\text { 3-Hydroxy-1-(4-hydroxy-3.5-dimethoxyphenyl)-1- } \\
\text { propanol }\end{array}$ & Nakasone et al. (1996) \\
\hline & 4-Hydroxyphenylacetic acid & Harish Nayaka et al. (2009) \\
\hline & Benzoic acid & Payet et al. (2005) \\
\hline & Chlorogenic acid & Galvez et al. (2008) \\
\hline & Coniferyl alcohol & Nakasone et al. (1996) \\
\hline & Ferulic acid & Payet et al. (2005), Singh et al. (2015) \\
\hline & Gallic & Harish Nayaka et al. (2009) \\
\hline & Gentisic acid & Harish Nayaka et al. (2009) \\
\hline & p-Coumaric acid & $\begin{array}{l}\text { Harish Nayaka et al. (2009), Payet et al. } \\
\text { (2005), Singh } \text { et al. (2015) }\end{array}$ \\
\hline & p-Hydroxy benzoic acid & Payet et al. (2005), Singh et al. (2015) \\
\hline & Protocatechuic acid & Harish Nayaka et al. (2009) \\
\hline & Synapil alcohol & Nakasone et al. (1996) \\
\hline & Syringaresinol & Nakasone et al. (1996) \\
\hline & Syringic acid & $\begin{array}{l}\text { Harish Nayaka et al. (2009), Payet et al. } \\
(2005) \text {, Singh et al. (2015) }\end{array}$ \\
\hline & Vanillic acid-vanillin & 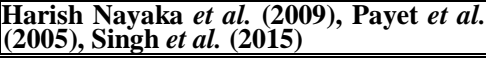 \\
\hline \multirow{18}{*}{$\frac{0}{0}$} & Medioresinol & Nakasone et al. (1996) \\
\hline & 3-Hydroxy-4,5-dimethoxyphenyl-b-D-glucopyranoside & Takara et al. (2002) \\
\hline & b-D-Fructofuranosyl-a-D-(6-syringil)-glucopyranoside & Takara et al. (2002) \\
\hline & $\begin{array}{l}\text { 3-Hydroxy-1-(4-hydroxy-3-methoxyphenil)-2-[4-(3- } \\
\text { hydroxy-1(E) propenyl) 2-methoxy phenoxy]propyl-b- } \\
\text { D-glucopyranoside }\end{array}$ & Takara et al. (2002) \\
\hline & $\begin{array}{l}\text { 3-Hydroxy-1-(4-hydroxy-3-methoxyphenyl)-2-[4-(3- } \\
\text { pydroxy-(E)- } 2,6- \\
\text { dimethoxyphenoxy]propyl-b-D-glucopyranoside }\end{array}$ & Takara et al. (2002) \\
\hline & Dehydrodiconiferyl alcohol-90-b-D-glucopyranoside & Takara et al. (2002) \\
\hline & \begin{tabular}{|l|} 
4-[Ethane-2-[3-(4-hydroxy-3-methoxyphenyl)-2- \\
propen]oxy]-2-dimethoxy-phenyl- \\
glucopyranoside
\end{tabular} & Takara et al. (2002) \\
\hline & $\begin{array}{l}\text { 4-[Ethane-2-[3-(4-hydroxy-3-methoxyphenyl)-2- } \\
\text { propen]oxy]-2- methoxy-phenyl-b-Dglucopyranoside }\end{array}$ & Takara et al. (2002) \\
\hline & $\begin{array}{l}\text { 4-(b-D-Glucopyranosyloxy)-3,5-dimethoxyphenyl- } \\
\text { propanone }\end{array}$ & Takara et al. (2003) \\
\hline & $\begin{array}{l}\text { 3-[5-[(Threo)2,3-dihydro-2-(4-hydroxy-3- } \\
\text { methoxyphenyl)-3- hydroxymethyl-7- } \\
\text { methoxybenzofurany]]-propanoic acid }\end{array}$ & Takara et al. (2003) \\
\hline & $\begin{array}{l}\text { 2-[4-(3-Hydroxy-1-propenyl)-2,6-dimethoxyphenoxy]- } \\
\text { 3-hydroxy-3-(4- } \\
\text { himethoxyphenyl)propyl-b-D-glucopyranoside }\end{array}$ & Takara et al. (2003) \\
\hline & $\begin{array}{l}\text { 4-[(Erythro)2,3-dihydro-3(hydroxymethyl)-5-(3- } \\
\text { hydropropyl)-7- methoxy-2-benzofuranyl]-2,6- } \\
\text { dimethoxyphenyl-b- glucopyranoside }\end{array}$ & Takara et al. (2003) \\
\hline & 9-O-b-D-Xylopyranoside of icariol A2 & Takara et al. (2003) \\
\hline & $\begin{array}{l}\text { 3-Hydroxy-1-(4-hydroxy-3,5-dimethoxyphenyl)-2-[4- } \\
\text { (3-hydroxy-1-(E) } \quad \text { propenyl)-2,6- } \\
\text { dimethoxyphenyl]propyl-b-D-glucopyranoside3-- } \\
\text { hydroxy-1-(4-hydroxy-3,5-dimethoxyphenyl)-2-[4-(3- } \\
\text { hydroxy-1-(E)-propenyl)-2,6- } \\
\text { dimethoxyphenyl]propyl-b-D-glucopyranoside }\end{array}$ & Takara et al. (2002) \\
\hline & 3,4-Dimethoxyphenyl-b-D-glucoside & $\begin{array}{l}\text { Kimura et al. (1984), Matsuura et al. } \\
\text { (1990) }\end{array}$ \\
\hline & 3,4,6-Trimethoxyphenyl-b-D-glucoside & Kimura et al. (1984) \\
\hline & $\begin{array}{l}\text { 3,4-Methoxy-4-hydroxyphenil-b-D-glucopyranoside } \\
\text { (tachioside) }\end{array}$ & Matsuura et al. (1990) \\
\hline & 4-Hydroxy-phenil-b-D-glucopyranoside (arbutin & Matsuura et al. (1990) \\
\hline
\end{tabular}

* Cited from W.R. Jaffe' / Journal of Food Composition and Analysis 43 (2015) 194-202 197. 
Harish, et al. (2009) reported that total phenolic content of 26.5, 31.5, 372 and $3837 \mu \mathrm{g}$ GAE/g for refined, white, brown and jaggery, respectively. From investigation, the presence of cytoprotective and antioxidant activity in jaggery and brown sugar may encourage their use for sweetening as well as for nutraceutical benefits.

Malnutrition among infants and young children is common in developing countries. Protein-energy and minerals malnutrition generally occurs during the crucial transitional phase when children are weaned from liquid to semi-solid or fully adult foods. Children need nutritionally balanced (Wondimu and Malleshi, 1996). Jaffe, (2015) reported that forty-two publications on chemical content and properties found to show that NCS (Jaggery) has nutritionally and functionally significant quantities of minerals, vitamins, and phenolics, among other constituents, as well as antioxidant capacities. This justifies its inclusion in food composition databases and in reviews of antioxidant properties and phenolic contents of foods. Higher awareness of the nutritional and functional properties of NCS could increase scientific, nutritional, and health interest in this food.

Biscuits and cakes are a group of snack food usually consumed by children and students because of their formers, high acceptability, and content of major required nutrients. Hence, the objective of this study was to produce cakes by replacing refined sugar with different levels $(20$, $40,60,80$, and $100 \%$ ) of Jaggery sugar. The effect of the replacement of refined sugar with these levels of Jaggery sugar on the nutritional, sensory, and storage characteristics were studied.

\subsection{Materials:}

\section{MATERIALS AND METHODS}

- Commercial refined wheat flour $72 \%$, sugar, butter, eggs, baking powder, skim milk powder, vanilla and Jaggery were purchased from the local market, which summarized in Table (3).

- Butter: Unsalted creamery butter (Anchor) was obtained from New Zealand Dairy Co., Board, 25 The Terrace, Wellington, New Zealand.

- Plate count agar, E. coli agar, potato dextrose agar media (HiMedia Mumbai, India) and petroleum ether (Merck chemicals, Mumbai, Maharashtra, India) were used for the studies.

\subsection{Methods:}

\section{1- Chemical analysis:}

- The proximate analysis of (wheat flour $72 \%$, Jaggery powder and other raw materials), such as moisture, fat, ash and total sugar contents were analyzed by using AACC International methods 44-19.01, 3025.01, 08-01.01 and 80-60.01, respectively AACC (2000). 
- The crude protein was determined using Kieldahle method according to A.O.A.C (2002).

- Zinc, iron and calcium content were determined using a Pye Unicom Sp 19000 atomic absorption spectroscopy techniques after dry ash according to the methods described in the A.O.A.C. (1995).

- Carbohydrates were estimated by difference according to (Chatfieled and Admas, 1940) as follows:

Available carbohydrates $=100-(\%$ protein $+\%$ fat $+\%$ ash $+\%$ fiber $+\%$ moisture $)$

- The energy value was calculated from the following equation as reported by Hawk, et al (1949).

Energy value $=4$ (total carbohydrates + protein $)+(9 \mathrm{x}$ fat $)$.

\section{2- preparation of sugars blends:}

$1-100 \%$ refined sugar.

2- $80 \%$ refined sugar $+20 \%$ Jaggery sugar.

3- $60 \%$ refined sugar $+40 \%$ Jaggery sugar.

4- $40 \%$ refined sugar $+60 \%$ Jaggery sugar.

$5-20 \%$ refined sugar $+80 \%$ Jaggery sugar.

6- $100 \%$ Jaggery sugar.

3- Cake processing: High- ratio cupcake type was processed using the method outlined by Abd El- Hadi, (2005) which summarized as follows: $100 \mathrm{gm}$ of wheat flour (soft) with baking powder were stirred together. The sugar was added to better and mixed until got smooth like cream by electric blender, and then well-blended eggs with vanillin were added and mixed together at low speed for 5 minutes, other ingredients as dried skimmed milk were added gradually and mixed at low speed for 5 minutes then at medium speed for 2 minutes until the mixtures were smooth. The mixtures transferred to a greased pan and were baked for $25 \mathrm{~min}$ at 180 $0 \mathrm{C}$ then were cooled at room temperature.

Table (3) Ingredients of Cake formula

\begin{tabular}{||l|c|}
\hline \multicolumn{1}{|c|}{ Ingredients } & Weight (gm) \\
\hline \hline Wheat flour 72\% & $\mathbf{1 0 0}$ \\
Baking powder & 3.2 \\
Sugar (powder sucrose) & $\mathbf{8 0}$ \\
Butter milk & $\mathbf{8 0}$ \\
Skim dry milk & $\mathbf{3 . 2}$ \\
Eggs (whole fresh eggs) & $\mathbf{8 0}$ \\
Vanillin & $\mathbf{2 . 0}$ \\
\hline
\end{tabular}

\section{4- Storage of cakes}

For storage studies, cakes with sugar; or with jaggery cooled, packed separately in polypropylene pouches and heat sealed. Cakes were stored at room temperature $\left(27 \pm 2{ }^{\circ} \mathrm{C}\right)$ and relative humidity $(65 \pm 5 \%)$ for 
21 days. The cakes samples were subjected to objective microbiological evaluation as described by (Ijah et al. 2014), on 0, 7th, 14th and 21st day.

\section{5- Physical properties for cakes}

Height, Weight, Volume and Specific volume were measured as mentioned by A.A.C.C (2002).

\section{6- Sensory characteristics for cakes}

The effect of the individual mixing of refined sugar or Jaggery with cakes ingredients was sensory evaluated to choose the best suitable substitution levels of refined sugar with Jaggery. Cakes samples were left to cool $\left(32^{\circ} \mathrm{C}\right)$ for $3 \mathrm{hrs}$. after baking then cake was cut with a sharp butcher knife and subjected to taste panel. Sensory evaluation of cake and Croissant was assessed by a group of 10 trained panelists. The score sheet shown in Table (4) as following:

Table (4) The Score Sheet of Sensory characteristics for cakes

\begin{tabular}{lc}
\hline Characteristics & Maximum score \\
\hline 1. Grain & $(20)$ \\
2. Texture & $(20)$ \\
2.1 Tenderness & $(5)$ \\
2.2 Softness & $(10)$ \\
2.3 moistness & $(5)$ \\
3. Crumb color & $(20)$ \\
4. Flavor & $(30)$ \\
4.1 Oder & $(15)$ \\
4.2 Taste & $(15)$ \\
5. Crust color & $(10)$ \\
\hline Over all acceptability & 100
\end{tabular}

The average of total score was converted to a descriptive category as follows: -

Very good (V.G) 90-100

Good (G) 80-89

Satisfactory (S) 70-79

Questionable (Q) less than 70

\section{7- Microbiological analysis of cakes:}

Total mesophilic (total viable bacterial counts), Salmonella, and E. coli counts of Jaggery and sugar cakes were analyzed over 21 days storage period. The samples were withdrawn weekly for analysis for 4 weeks. Cakes samples were prepared by mashing and mixing in peptone water. Subsequently, samples were diluted decimally and $0.1 \mathrm{~mL}$ aliquots were inoculated on Plate Count Agar (PCA), Potato Dextrose Agar (PDA) via pouring plate technique for the enumeration of aerobic 
bacteria and yeast and mold, respectively. EMB broth with inverted Durham's tubes and Rappaport-Vassiliadis R10 Broth was inoculated with the samples for detection coliforms and Salmonella, respectively (Ijah et al., 2014). All inoculated plates and tubes were incubated at $37^{\circ} \mathrm{C}$ for $24-48 \mathrm{~h}$ except for PDA plates which were incubated at room temperature $\left(28 \pm 2 \_\right.$C) for 3-5 days. The colonies were then counted and expressed as colony-forming units per gram (CFU/g) of samples. Broth inoculated cultures for the detection of E. coli and Salmonella were observed for the gas formation and color change, respectively.

\section{8- Statistical analysis:}

Data of the sensory evaluation of cakes were analyzed by the Analysis of variance (ANOVA) were completed using the statistical package for the social (SPSS 2000, Chicago); $p<0.05$ was considered significant. Specific differences between treatments were determined by LSD test for each attribute. Results were tested for degree of significant level at $\mathrm{p}<0.05$ (Snedecor and Cochran, 1976).

\section{RESULTS AND DISCUSSION}

\section{1 -Chemical composition of raw materials:}

The chemical composition of jaggery, sucrose (refined sugar), wheat flour $72 \%$ ex., butter, whole fresh egg and skim-milk powder was studied and the obtained results are shown in table (5).

Table (5) Chemical composition of raw food materials $(\mathrm{g} / 100 \mathrm{~g}$ on dry weight basis) .

\begin{tabular}{|c|c|c|c|c|c|c|c|c|}
\hline \multirow[t]{3}{*}{ Samples No. } & \multirow{3}{*}{$\begin{array}{c}\text { Moisture } \\
\%\end{array}$} & \multirow{3}{*}{$\begin{array}{c}\text { Energy } \\
\text { Cal/100gm }\end{array}$} & \multicolumn{6}{|c|}{ As a dry basis } \\
\hline & & & \multirow{2}{*}{$\begin{array}{c}\text { Protein } \\
\%\end{array}$} & \multirow{2}{*}{$\begin{array}{c}\text { Fat } \\
\%\end{array}$} & \multirow{2}{*}{$\begin{array}{c}\text { Crude } \\
\text { fiber } \\
\%\end{array}$} & \multirow{2}{*}{$\begin{array}{c}\text { Ash } \\
\%\end{array}$} & \multicolumn{2}{|c|}{$\begin{array}{c}\text { Total carbohydrates } \\
\%\end{array}$} \\
\hline & & & & & & & Sucrose & $\begin{array}{l}\text { reducing } \\
\text { sugars }\end{array}$ \\
\hline Jaggery & 13.3 & 387 & 1.6 & 0.0 & 0.0 & 2.89 & 82.59 & 12.56 \\
\hline $\begin{array}{l}\text { Sucrose } \quad \text { (refined } \\
\text { sugar) }\end{array}$ & 0.81 & 399 & 0.0 & 0.0 & 0.0 & 0.20 & 99.9 & 0.0 \\
\hline Wheat flour 72\% ex. & 13.8 & 398 & 10.15 & 0.74 & 0.76 & 0.61 & \multicolumn{2}{|c|}{87.74} \\
\hline Butter & 16.3 & 875 & 1.07 & 96.77 & - & 2.11 & \multicolumn{2}{|c|}{0.05} \\
\hline Whole egg (fresh) & 74.5 & 605 & 47.37 & 45.1 & - & 5.2 & \multicolumn{2}{|c|}{2.33} \\
\hline Skim-milk powder & 9.4 & 373 & 34.5 & $\mathbf{0 . 3 2}$ & - & 7.1 & \multicolumn{2}{|c|}{58.08} \\
\hline
\end{tabular}

From the results, it could be noticed that the sucrose content of refined sugar was higher than jaggery, while jaggery had reducing sugars more than refined sugar. Protein, fat and crude fiber contents of jaggery and refined sugar were lower than wheat flour and other raw materials.

A whole fresh egg has the highest percentage of protein $(47.37 \%)$, followed by skim milk powder (34.5\%). Butter has the highest percentage of energy, and fat, while refined sugar has the highest percentage of total carbohydrates. 
These results are in agreement with those reported by Jayamala et al., (2009) who mentioned that total calories (KCal), protein (g), carbohydrates $(\mathrm{g})$, fat $(\mathrm{g})$, sodium $(\mathrm{mg})$, total sugars $(\mathrm{g})$, dietary fiber $(\mathrm{g})$ and minerals $(\mathrm{mg})$ were $308.0(\mathrm{KCal})$, Trace, $77.0(\mathrm{~g})$, Trace, Trace, 77.0 $(\mathrm{g})$, Trace and $>2000.0(\mathrm{mg})$ per $100 \mathrm{~g}$ of Jaggery, respectively. The jaggery powder had higher moisture, ash content, and lower total sugar when compared to sugar.

Guerra and Mujica (2008) reported that the parameters with higher variability of jaggery were moisture (1.66-4.36 g.100 g-1), aw (0.51-0.69), reducing sugars (4.58-11.48 g.100 g-1), $\mathrm{pH}(5.58-6.90)$.

The sugar and jaggery powder had 0.81 and $6.90 \%$ moisture, ash (0.2 and $1.56 \%$ ), and total sugar (96 and 69.23\%). These results show that the jaggery is rich in minerals. The moisture and total sugar contents of jaggery are within the limits specified by Fssai (2017).

The published proximate composition of NCS (jaggery) and sucrose is the most important component, between 76.55 and $89.48 \%$, followed by reducing sugars (3.69-10.5\%) and moisture (1.5-15.8\%). The relatively large range of moisture content is caused by differences in the manufacturing process conditions of this mainly artisanal product. The mineral content (ashes) is relatively high (0.3-3.6\%). Protein content ranges between 0.37 and $1.7 \%$ and fats between 0 and $0.1 \%$. No fiber has been reported. The basic difference between NCS and refined sugar is the presence in the first of reducing sugars and of significant quantities of minerals and other minor constituents. The nutritional and functional difference will then primarily depend on these minor constituents (Jaffe, 2015).

\section{2- Minerals content of jaggery, sucrose (refined sugar), wheat flour $72 \%$ ex., and other raw materials:}

Minerals' contents of jaggery, sucrose (refined sugar), wheat flour $72 \%$ ex., and other raw materials were determined (Table 6). The results indicated that jaggery was extremely rich in minerals as compared with refined sugar, wheat flour, and butter. Jaggery has the highest percent of Iron and Copper, while skim milk has the highest percent of Calcium, Zinc, Potassium, Sodium, and Magnesium (Mg). Refined sugar was extremely poor in minerals.

These results agree with those of Singh et al., (1978) who reported that the granular jaggery is rich in minerals $(0.6-1 \%)$ as it contains 9 $\mathrm{mg} \%$ calcium, $4 \mathrm{mg} \%$ phosphorous, and $12 \mathrm{mg} \%$ iron.

Guerra and Mujica (2008) studied the physical and chemical properties of granulated cane sugar "Panela" (jaggery). Potassium was the most abundant mineral (229.52-1027.18 mg.100 g-1).

Minerals contents per $100 \mathrm{~g}$ of jaggery were ranged between 13.70 $-240.00 \mathrm{mg}$ of Calcium, 5.30 - $250.00 \mathrm{mg}$ of Chloride, $9.90-9.90 \mu \mathrm{g}$ of 
Cobalt, 0.17-8.50 mg of Copper, 11.90 - $16.00 \mu \mathrm{g}$ of Chromium, 0.01$0.01 \mu \mathrm{g}$ of Iodine, $1.60-12.50 \mathrm{mg}$ of Iron, $31.00-120.00 \mathrm{mg}$ of Magnesium, 0.35 - $1.66 \mathrm{mg}$ of Manganese, 2.00 - $125.00 \mathrm{mg}$ of Phosphorus, $14.05-1100.00 \mathrm{mg}$ of potassium, $15.50-79.00 \mathrm{mg}$ of Sodium and $0.10-1.76 \mu \mathrm{g}$ Zinc. The wide range of values for the components presumably reflect differences between sugarcane varieties, agronomical, and process conditions (Jaffe, 2015).

Table (6) Minerals content of raw food materials (mg / $100 \mathrm{~g}$ on dry weight basis).

\begin{tabular}{|c|c|c|c|c|c|c|}
\hline $\begin{array}{l}\text { Minerals } \\
\text { content } \\
\text { mg / 100 g }\end{array}$ & Jaggery & $\begin{array}{c}\text { Sucrose } \\
\text { (refined } \\
\text { sugar) }\end{array}$ & $\begin{array}{l}\text { Wheat } \\
\text { flour }\end{array}$ & $\begin{array}{c}\text { Skim } \\
\text { milk } \\
\text { powder }\end{array}$ & $\begin{array}{c}\text { Whole } \\
\text { fresh egg }\end{array}$ & Butter \\
\hline IRON (Fe) & 3.41 & 0.1 & 2.26 & 0.6 & 2.5 & 0.18 \\
\hline Calcium (Ca) & 128.5 & 0.0 & 21.3 & 1299 & 69.7 & 23.9 \\
\hline Zinc (Zn) & 0.51 & 0.0 & 0.45 & 4.9 & 0.8 & - \\
\hline Potassium (k) & 344.09 & 3.0 & 146.06 & 1620.3 & 132.4 & 25.66 \\
\hline Sodium (Na) & 29.3 & 0.0 & 3.16 & 523.7 & 127.7 & 550 \\
\hline Magnesium (Mg) & 93.33 & 1.63 & 26.12 & 155.3 & 95.7 & - \\
\hline Manganese (Mn) & 0.41 & 0.0 & 0.67 & 0.5 & 8.0 & - \\
\hline Copper $(\mathbf{C u})$ & 0.58 & 0.0 & 0.42 & - & - & - \\
\hline
\end{tabular}

3-Nutritional properties and sensory evaluation of cake made by substitution of refined sugar with jaggery.

a) Nutritional properties and sensory evaluation of cake:

\section{1- Chemical composition:}

The chemical composition of cake produced by substitute refined sugar (sucrose) with jaggery are presented in table (7).

Table (7) Chemical composition of cake produced by substitute refined sugar (sucrose) with Jaggery.

\begin{tabular}{|c|c|c|c|c|c|c|c|c|}
\hline \multirow[b]{2}{*}{$\begin{array}{l}\text { Sample } \\
\text { No. }\end{array}$} & \multirow[t]{2}{*}{ Blends } & \multirow{2}{*}{$\begin{array}{l}\text { Energy } \\
\text { Cal./ } \\
100 \text { gm } \\
\text { cake }\end{array}$} & \multirow{2}{*}{$\begin{array}{c}\text { Moisture } \\
\%\end{array}$} & \multicolumn{5}{|c|}{ As a dry basis } \\
\hline & & & & $\begin{array}{c}\text { Protein } \\
\%\end{array}$ & $\begin{array}{c}\text { Fat } \\
\%\end{array}$ & $\begin{array}{c}\text { Fiber } \\
\%\end{array}$ & $\begin{array}{c}\text { Ash } \\
\%\end{array}$ & $\begin{array}{c}\text { \%otal } \\
\text { carbohydrat } \\
\mathrm{e}\end{array}$ \\
\hline 1 & $100 \%$ sucrose & 441.0 & 18.14 & 7.78 & 28.92 & 0.26 & 1.30 & 61.74 \\
\hline 2 & \begin{tabular}{|l|l|}
$80 \% \quad$ sucrose & $+20 \%$ \\
Jaggery
\end{tabular} & 438.0 & 18.78 & 7.93 & 29.15 & 0.26 & 1.45 & 61.22 \\
\hline \multicolumn{2}{|c|}{$\%$ change from control } & -0.68 & $\mathbf{3 . 5 3}$ & 1.93 & $\mathbf{0 . 8 0}$ & - & 11.54 & -0.84 \\
\hline 3 & \begin{tabular}{|ll}
$\begin{array}{l}60 \% \\
\text { Jaggery }\end{array}$ & sucrose \\
\end{tabular} & 435.0 & 19.41 & 8.07 & 29.37 & 0.26 & 1.61 & 60.69 \\
\hline \multicolumn{2}{|c|}{$\%$ change from control } & -1.36 & 7.00 & 3.73 & 1.56 & - & 23.85 & -1.70 \\
\hline 4 & $\begin{array}{l}40 \% \text { sucrose } \quad+60 \% \\
\text { Jaggery }\end{array}$ & 431.0 & 20.10 & 8.23 & 29.61 & 0.26 & 1.77 & 60.13 \\
\hline \multicolumn{2}{|c|}{ \% change from control } & -2.27 & 10.8 & 5.78 & 2.39 & - & 36.15 & -2.61 \\
\hline 5 & \begin{tabular}{|ll}
$\begin{array}{l}20 \% \\
\text { Jaggery }\end{array}$ & sucrose \\
\end{tabular} & 429.0 & 20.68 & 8.38 & 29.84 & 0.26 & 1.93 & 59.60 \\
\hline \multicolumn{2}{|c|}{$\%$ change from control } & -2.72 & 14.0 & 7.71 & 3.18 & - & 48.46 & -3.47 \\
\hline 6 & |100\% Jaggery & 426.0 & 21.31 & 8.54 & 30.08 & $\mathbf{0 . 2 7}$ & 2.09 & 59.0 \\
\hline \multicolumn{2}{|c|}{$\%$ change from control } & -3.40 & 17.48 & 9.77 & 4.01 & 3.85 & 60.77 & -4.44 \\
\hline
\end{tabular}


From the previous results it could be noticed that moisture, protein, fat and ash contents of cakes increased by increasing the level of replacement. Moisture, Protein, fat and ash contents increased from 18.14, 7.78, 28.92 and $1.3 \%$ for sample No. 1 (control sample) to 21.31, 8.54, 30.08 and 2.09 $\%$ for sample No. 6, respectively. From the same results it could be noticed that the increments from control (sample No. 1) were ranged from 3.53 to $17.48 \%$ for moisture contents, from 1.93 to $9.77 \%$ for protein contents, and from 0.80 to $4.01 \%$ for fat and from 11.54 to $60.77 \%$ for ash contents. Ash content increased by about 1.6 times like control at level $100 \%$ replacement. Total carbohydrates and energy (cal./ 100gm of cake) tended to decrease by increasing the replacement level of refined sugar with jaggery.

Jayamala et al., (2009) reported that the jaggery muffins showed higher values for moisture, ash, lower protein, fat and total sugar contents when compared to muffins with sugar.

The results of Lamdande, et al. (2018) for evaluation of physicochemical characteristics of both the muffins showed that the moisture content of muffins prepared with jaggery was higher $(21.8 \%)$ than muffins prepared with sugar $(19.6 \%)$ due to presence of invert sugar, mineral salts which are hygroscopic in nature and also higher moisture content present in the jaggery (Mandal et al. 2006). The protein and fat contents were slightly lower (6.38 and $30.93 \%)$ in muffins with jaggery than muffins with sugar (6.58 and $33.33 \%)$. The ash content of muffins was higher in muffins with jaggery $(1.21 \%)$ than muffins with sugar $(0.82 \%)$. The sugar content in muffins with jaggery muffins was found to be $27.8 \%$, which is considerably lower than the muffins with sugar (32.4\%). The increase in ash and decrease in sugar contents in muffins with jaggery than muffins with sugar is due to the presence of higher amount of minerals like iron, calcium, phosphorous and lower amount of sucrose in jaggery when compared to sugar (Jagannadha Rao et al. 2007).

\section{2- Minerals content:}

Minerals contents of cakes were tabulated in table (8).

Results indicated that minerals contents of cakes increased by increasing the level of replacement of refined sugar with jaggery. $\mathbf{C a}, \mathbf{Z n}$, $\mathbf{C u}, \mathbf{M n}, \mathbf{F e}, \mathbf{K}, \mathbf{N a}$ and $\mathbf{M g}$ content increased about 2.15, 1.6, 2.2, 1.27, $2.13,2.18,1.09$ and 2.43 times respectively, like control at level $100 \%$ replacement (sample 6).

These results show that sample 6 (100\% jaggery) could be claimed to be a high source for Manganese Mn, Sodium Na, Magnesium Mg and Copper $\mathrm{Cu}$, represent 54.5, 43.49, 28.3 and $20.53 \%$, respectively of the Recommended Daily Dietary Allowances (for children 7-10 years) and a good source for iron Fe and Potassium K represent 16.69 and $11.41 \%$ of the Recommended Daily Dietary Allowances (for children 7-10 years) according to the Food Nutrition Board, National Academy of Sciences-National Research Council Recommended Daily Dietary Allowances (1989). 
Table (8) Minerals content of cake produced by substitute sugar (sucrose) with Jaggery (mg /100g on dry weight basis)

\begin{tabular}{|c|c|c|c|c|c|c|c|c|c|}
\hline \begin{tabular}{c|} 
Sample \\
No.
\end{tabular} & Blends & $\begin{array}{c}\mathrm{Ca} \\
(\mathbf{m g})\end{array}$ & $\begin{array}{c}\mathrm{Zn} \\
(\mathrm{mg})\end{array}$ & $\begin{array}{c}\mathrm{Cu} \\
(\mathrm{mg})\end{array}$ & $\begin{array}{l}\text { Mn } \\
(\mathrm{mg})\end{array}$ & $\begin{array}{c}\text { Fe } \\
(\mathrm{mg})\end{array}$ & $\begin{array}{c}\mathrm{K} \\
(\mathrm{mg})\end{array}$ & $\begin{array}{c}\mathrm{Na} \\
(\mathrm{mg})\end{array}$ & $\begin{array}{l}\text { Mg } \\
(\mathrm{mg})\end{array}$ \\
\hline \multicolumn{2}{|c|}{$\begin{array}{l}\text { Recommended Daily Dietary } \\
\text { Allowances for children 7-10 years } \\
\text { (1989) }\end{array}$} & 800 & 10 & 1.5 & 2 & 12 & 1600 & 400 & 160 \\
\hline 1 & $100 \%$ sucrose & 32.43 & 0.260 & 0.14 & 0.86 & 0.94 & 83.68 & 158.93 & 18.49 \\
\hline \multicolumn{2}{|c|}{ \% of Reference Daily Intake (RDI) } & 4.05 & 2.60 & 9.33 & 43.00 & 7.83 & 5.23 & 39.73 & 11.56 \\
\hline 2 & $\begin{array}{l}80 \% \text { sucrose }+20 \% \\
\text { Jaggery }\end{array}$ & 39.72 & 0.294 & 0.173 & 0.889 & 1.230 & 102.99 & 162.16 & 23.64 \\
\hline \multicolumn{2}{|c|}{ \% of Reference Daily Intake (RDI) } & 4.97 & 2.94 & 11.53 & 444.45 & 10.25 & 6.44 & 40.54 & 14.78 \\
\hline 3 & $\begin{array}{l}\text { 60\% sucrose }+40 \% \\
\text { Jaggery }\end{array}$ & 47.045 & 0.324 & 0.206 & 0.918 & 1.416 & 122.39 & 165.42 & 28.81 \\
\hline \multicolumn{2}{|c|}{ \% of Reference Daily Intake (RDI) } & 5.88 & 3.24 & 13.73 & 45.90 & 11.8 & 7.65 & 41.36 & 18.0 \\
\hline 4 & $\begin{array}{l}40 \% \text { sucrose }+60 \% \\
\text { Jaggery }\end{array}$ & 54.49 & 0.355 & 0.239 & 0.948 & 1.609 & 142.11 & 167.96 & 34.076 \\
\hline \multicolumn{2}{|c|}{ \% of Reference Daily Intake (RDI) } & 6.81 & 3.55 & 15.93 & 47.40 & 13.41 & 8.88 & 41.99 & 21.30 \\
\hline 5 & \begin{tabular}{|l|}
$20 \%$ sucrose $+\mathbf{8 0} \%$ \\
Jaggery
\end{tabular} & 62.05 & 0.386 & 0.273 & 1.016 & 1.800 & 162.13 & 170.9 & 39.42 \\
\hline \multicolumn{2}{|c|}{ \% of Reference Daily Intake (RDI) } & 7.76 & 3.86 & 18.2 & $\begin{array}{l}50.8 \\
\end{array}$ & 15.0 & 10.13 & 42.73 & 24.64 \\
\hline 6 & $100 \%$ Jaggery & 69.73 & 0.418 & 0.308 & 1.09 & 2.003 & 182.48 & 173.94 & 44.85 \\
\hline \multicolumn{2}{|c|}{ \% of Reference Daily Intake (RDI) } & 8.72 & 4.18 & 20.53 & 54.5 & 16.69 & 11.41 & 43.49 & 28.03 \\
\hline
\end{tabular}

Food Nutrition Board, National Academy of Sciences-National Research Council Recommended Daily Dietary Allowances (1989).

The high contents of minerals in jaggery raise the nutritive value of cake products. These results are in agreement with those reported by FDA, (2008) these results show that NCS could be claimed to be a high source for copper (more than 20\% of the RDI) and a good source for iron and manganese (between 10 and 19\% of the RDI) according to the U.S. Food and Drugs Administration (FDA) regulations on health claims on food. Additionally, chromium, magnesium, potassium, niacin and vitamin B6 in NCS supply between 5 and 9\% of the RDI for these nutrients. In contrast refined sugar practically does not contain minerals and vitamins.

To be considered "healthy" by the FDA a food must not only meet the criteria of not exceeding predefined levels of total fat, saturated fat, cholesterol and sodium, but also provide $10 \%$ or more of the DRV of protein, fiber, vitamin A, vitamin C, calcium or iron. In this sense, NCS is healthy as it does not exceed the above levels and provides more than $10 \%$ of daily iron requirements (Jaffe, 2015).

b- Sensory evaluation and Physical properties of cake:

Sensory evaluation of cakes prepared with varying levels of refined sugar (sucrose) substitution with Jaggery is shown in table (9). 
Table (9) Sensory characteristics of cake made by substitute refined sugar (sucrose) with Jaggery.

\begin{tabular}{|c|c|c|c|c|c|c|c|}
\hline \multirow{3}{*}{ Samples } & \multirow{2}{*}{ Crust color } & \multicolumn{3}{|c|}{$\begin{array}{c}\text { Internal } \\
\text { Characteristic }\end{array}$} & \multicolumn{2}{|c|}{ Flavor } & \multirow[t]{2}{*}{$\begin{array}{c}\text { Overall } \\
\text { acceptability }\end{array}$} \\
\hline & & Crumb color & Crumb grain & Texture & Taste & Odor & \\
\hline & 10 & 20 & 20 & 20 & 15 & 15 & 100 \\
\hline 1) $100 \%$ sucrose & $9.79^{\mathrm{a}} \pm 0.34$ & $19.15^{\mathrm{a}} \pm 0.34$ & $19.58^{\mathrm{a}} \pm 0.34$ & $19.14^{\mathrm{a}}{ }_{ \pm 0.34}$ & $14.70^{\mathrm{a}} \pm 0.34$ & $14.82^{\mathrm{a}} \pm 0.34$ & $95.7^{a} \pm 0.34$ \\
\hline $\begin{array}{l}\text { 2) } 80 \% \text { sucrose } \\
+20 \% \text { Jaggery }\end{array}$ & $8.21^{b} \pm 0.34$ & $16.5^{b} \pm 0.34$ & $18.42^{\mathrm{ab}} \pm 0.34$ & $18.72^{\mathrm{a}} \pm 0.34$ & $14.36^{a} \pm 0.34$ & $14.00^{\mathrm{ab}} \pm 0.34$ & $86.4_{ \pm 0.34}^{b}$ \\
\hline $\begin{array}{l}\text { 3) } 60 \% \text { sucrose } \\
+40 \% \text { Jaggery }\end{array}$ & $7.71^{b c_{ \pm 0.34}}$ & $15.92^{b c} \pm 0.34$ & $16.52^{b c} \pm 0.34$ & $17.28^{\mathrm{ab}} \pm 0.34$ & $14.15^{\mathrm{a}} \pm 0.34$ & $12.78^{b c} \pm 0.34$ & $82.9^{b c} \pm 0.34$ \\
\hline $\begin{array}{l}\text { 4) } 40 \% \text { sucrose } \\
+60 \% \text { Jaggery } \\
\end{array}$ & $6.86^{\mathrm{cd}} \pm 0.34$ & $14.43^{\mathrm{cd}} \pm 0.34$ & $15.00^{c d} \pm 0.34$ & $16.58^{b} \pm 0.34$ & $13.20^{a b} \pm 0.34$ & $12.54^{\mathrm{c}} \pm 0.34$ & $80.0^{\mathrm{cd}}{ }_{ \pm 0.34}$ \\
\hline $\begin{array}{l}\text { 5) } 20 \% \text { sucrose } \\
+\mathbf{8 0 \%} \text { Jaggery }\end{array}$ & $6.71_{ \pm 0.34}^{\mathrm{cd}}$ & $14.00^{d}{ }_{ \pm 0.34}$ & $14.40^{\mathrm{cd}} \pm 0.34$ & $16.00^{b} \pm 0.34$ & $12.54^{b c} \pm 0.34$ & $12.03{ }^{c} \pm 0.34$ & $77.9^{\mathrm{de}_{ \pm 0.34}}$ \\
\hline $\begin{array}{l}\text { 6) } 100 \% \\
\text { Jaggery }\end{array}$ & $6.14^{d}{ }_{ \pm 0.34}$ & $13.28^{d}{ }_{ \pm 0.34}$ & $13.28 \mathrm{~d}_{ \pm 0.34}$ & $15.58^{b} \pm 0.34$ & $11.46^{c} \pm 0.34$ & $11.52^{c} \pm 0.34$ & $75.7^{\mathrm{e}} \pm 0.34$ \\
\hline L.S.D. & 1.06 & 1.8 & 2.17 & 2.06 & 1.52 & 1.37 & $\begin{array}{l}4.13 \\
\end{array}$ \\
\hline
\end{tabular}

The water absorptive properties showed gradually increase with raising the substitution levels of refined sugar (sucrose) substitution with Jaggery, and therefore, these doughs needed more water than the control, to have the same consistency.

Cakes specific volume decreased as refined sugar (sucrose) substitution with Jaggery and became more compressed than control. Results recorded in Table (10) showed that all organoleptic attributes of cakes produced from different levels of refined sugar (sucrose) substitution with Jaggery were significantly affected by this substitution. The overall acceptability values were decreased with each increment of refined sugar replacement with Jaggery. Cakes prepared with substitution levels $100 \%$ had the lowest scores of all organoleptic attributes.

Table (10) Physical characteristics of cake made by substitute refined sugar (sucrose) with Jaggery.

\begin{tabular}{||l||c||c||c||}
\hline \multicolumn{1}{|c||}{ Samples } & $\begin{array}{c}\text { Volume } \\
\left(\mathrm{cm}^{3}\right)\end{array}$ & $\begin{array}{c}\text { Weight } \\
(\mathrm{g})\end{array}$ & $\begin{array}{c}\text { Specific volume } \\
\left(\mathrm{cm}^{3} / \mathrm{g}\right)\end{array}$ \\
\hline 1 ) 100\% sucrose & 112.0 & 45.8 & 2.45 \\
\hline 2) $80 \%$ sucrose +20\% Jaggery & 105.0 & 46.41 & 2.26 \\
\hline 3$) 60 \%$ sucrose +40\% Jaggery & 100.0 & 46.87 & 2.13 \\
\hline 4) 40\% sucrose +60\% Jaggery & 99.0 & 47.16 & 2.10 \\
\hline 5) 20\% sucrose +80\% Jaggery & 106.0 & 46.11 & 2.30 \\
\hline 6) 100\% Jaggery & 101.0 & 46.72 & 2.16 \\
\hline
\end{tabular}

In conclusion, substituting of refined sugar with Jaggery could enhance the nutritive value of cake as shown by chemical analysis, but Baking quality and sensory evaluation of cakes indicated that replacement of refined sugar with Jaggery were satisfactory until $100 \%$ level.

Similar results were reported by Jayamala et al., (2009) who mentioned that the Jaggery muffins showed lower value for lightness, higher 
values for redness and yellowness than sugar muffins. For the preparation of Jaggery muffins having quality characteristics closer to sugar muffins. The overall quality score of muffins with Jaggery was lower than the muffins with sugar. Texture characteristics and overall quality score for the muffins with Jaggery when compared to muffins with sugar during storage for 21 days. Hence, it can be concluded that Jaggery can be used for the total replacement sugar on equal weight basis in various bakery products in future.

\section{b- Microbial analyses of cake:}

The results of microbial analyses of cake performed as a part of storage studies are shown in table (11).

Microbial analysis has shown that E. coli and Salmonella were not detected in both the cakes samples (with sugar and Jaggery). The total bacterial count, yeast and mold count increased for cakes with jaggery or sugar with increase in storage period from 0 to 21 days. The microbial load was higher in Jaggery cakes as compared to sugar-based cakes over a storage period of 21 days. There was considerable increase seen in fungi and bacteria in the third week. Hence, it can be concluded that the cakes stored for 21 days was microbiologically safe and should be consumed before the end of that period. Similar results were reported by Lamdande et al., (2018).

Table (11) Microbial analyses as a part of storage studies of cake made by substitute refined sugar (sucrose) with Jaggery.

\begin{tabular}{|c|c|c|c|c|c|c|}
\hline \multirow{2}{*}{ No. } & \multirow{2}{*}{\begin{tabular}{||l|} 
Microbial analyses \\
Storage period(day) \\
\end{tabular}} & \multicolumn{5}{|c|}{ Total bacterial count } \\
\hline & & $\mathbf{0}$ & 2 & 7 & 14 & 21 \\
\hline 1 & $100 \%$ sucrose & ND & ND & $7.0 \times 10$ & $8.0 \times 10^{2}$ & $9.9 \times 10^{2}$ \\
\hline 2 & $80 \%$ sucrose $+20 \%$ Jaggery & ND & ND & $10.6 \times 10$ & $14.5 \times 10^{2}$ & $18 \times 10^{2}$ \\
\hline 3 & $60 \%$ sucrose $+40 \%$ Jaggery & $6 \times 10$ & $8 \times 10$ & $12 \times 10$ & $13.3 \times 10^{2}$ & $16 \times 10^{2}$ \\
\hline 4 & $40 \%$ sucrose $+60 \%$ Jaggery & $6 \times 10$ & $7 \times 10$ & $1.0 \times 10^{2}$ & $2.0 \times 10^{2}$ & $3.7 \times 10^{2}$ \\
\hline 5 & $20 \%$ sucrose $+80 \%$ Jaggery & $5 \times 10$ & $7 \times 10$ & $5 \times 10$ & $1.6 \times 10^{2}$ & $2.6 \times 10^{2}$ \\
\hline 6 & $100 \%$ Jaggery & $6 \times 10$ & $8 \times 10$ & $19 \times 10$ & $4.7 \times 10^{2}$ & $2.3 \times 10^{2}$ \\
\hline \multirow{2}{*}{ No. } & Microbial analyses & \multicolumn{5}{|c|}{ E. coli } \\
\hline & Storage period(day) & $\mathbf{0}$ & 2 & 7 & 14 & 21 \\
\hline 1 & $100 \%$ sucrose & ND & ND & ND & ND & ND \\
\hline 2 & $80 \%$ sucrose $+20 \%$ Jaggery & ND & ND & ND & ND & ND \\
\hline 3 & $60 \%$ sucrose $+40 \%$ Jaggery & ND & ND & ND & ND & ND \\
\hline 4 & $40 \%$ sucrose $+60 \%$ Jaggery & ND & ND & ND & ND & ND \\
\hline 5 & $20 \%$ sucrose $+80 \%$ Jaggery & ND & ND & ND & ND & ND \\
\hline 6 & 100\% Jaggery & ND & ND & ND & ND & ND \\
\hline \multirow{2}{*}{ No. } & Microbial analyses & \multicolumn{5}{|c|}{ Salmonella spp. } \\
\hline & Storage period(day) & $\mathbf{0}$ & 2 & 7 & 14 & 21 \\
\hline 1 & $100 \%$ sucrose & ND & ND & ND & ND & ND \\
\hline 2 & $80 \%$ sucrose $+20 \%$ Jaggery & ND & ND & ND & ND & ND \\
\hline 3 & $60 \%$ sucrose $+40 \%$ Jaggery & ND & ND & ND & ND & ND \\
\hline 4 & $40 \%$ sucrose $+60 \%$ Jaggery & ND & ND & ND & ND & ND \\
\hline 5 & $20 \%$ sucrose $+80 \%$ Jaggery & ND & ND & ND & ND & ND \\
\hline 6 & 100\% Jaggery & ND & ND & ND & ND & ND \\
\hline
\end{tabular}




\section{REFERENCES}

A.O.A.C. (1995). Official Methods of the Association of Official Analytical Chemists. 16th ed., Arlington, Virginia, U.S.A.

A.O.A.C. (2002). Official Methods of Analysis. Association of Official Analytical Chemists, A.O.A.O International (17th Ed.). Revision I, 2002, Maryland, U.S.A.

AACC. (2002). American Association of Cereal Chemists, methods 54- 21, In: Approved Methods of The American Association of Cereal Chemist, The Association, St. Pull, MN., USA.

Abd El-Hadi, A. A. (2005). Evaluation of volatile oils produced from same food processing and farm wastes. Ph.D. Thesis, Fac. of Agric., Cairo Univ., Egypt

American Association of Cereal Chemists (AACC) (2000). Approved methods of American Association of Cereal Chemists (9th ed.), Moisture (44-19.01), Ash (08-01.01), fat (30-25.01), total sugar (8060.01) and modified amylograph (22-10.01) method. AACC International, St. Paul Minnesota, USA

Chatfield, C. and G. Adams (1940). Proximate composition of American food. Material, MDSA, Cir 549.

De Souza, V.R. ; P.A.P. Pereira ; A.C.M. Pinheiro ; H.M.A. Bolini ; S.V. Borges and F. Queiroz (2013). Analysis of various sweeteners in low-sugar mixed fruit jam: equivalent sweetness, time intensity analysis and acceptance test. Int J Food Sci Technol., 48:1541-1548.

FDA (US Food and Drug Administration), (2008). 101.9 Nutrition labeling of food. Code of Federal Regulations, Title 21, Food and Drugs, vol. 2Food and Drug Administration, pp. 18-19 (Chapter I).

Food Nutrition Board (1989). National Academy of Sciences-National Research Council Recommended Daily Dietary Allowances.

FSSAI (2017). Standards for Gur or jaggery, sodium saccharin and calcium saccharin. Food Safety and Standards Authority of India, Ministry of health and Family Welfare, Government of India, New Delhi, p 5.

Guerra, M. J. and M. V. Mujica (2008). Physical and chemical properties of granulated cane sugar "panelas". Ciênciae Tecnologia de Alimentos, ISSN 0101-2061.

Halliwell, B. (2007). Oxidative stress and cancer: Have we moved forward? Biochemical Journal, 401: 1-11.

Harish Nayaka, M.A.; U.V.Sathisha; M.P.Manohar; K.B. Chandrashekar and S. M. Dharmesh (2009). Cytoprotective and antioxidant activity studies of jaggery sugar. Food Chemistry., 115: 113-118.

Hawk, P.D. ; B.L. Oser and W.H.L. Summerson (1949). Practical physiological chemistry. J. Nutr., 12, 962. 
Ijah, U.J.J. ; H.S. Auta ; M.O. Aduloju and S.A. Aransiola (2014) Microbiological, nutritional, and sensory quality of bread produced from wheat and potato flour blends. Int J Food Sci. https://doi.org/10. $1155 / 2014 / 671701$

Jaffe, W. R. (2012). Health Effects of Non-Centrifugal Sugar (NCS): A Review. Sugar Tech (Apr-June 2012) 14(2):87-94.

Jaffe, W. R. (2015). Nutritional and functional components of non-centrifugal cane sugar: A compilation of the data from the analytical literature. Journal of Food Composition and Analysis., 43:194-202.

Jagannadha Rao, P.V.K. ; Das Madhusweta and S.K. Das (2007) Jaggerya traditional Indian sweetener. Indian J Tradit Knowl., 6:95-102

Jayamala, G.B.;M. Chowde Gowda ; H.N. Ramya ; M. Shankar and P.N. Krishnamma (2009): Prospects of Jaggery Industry in Karnataka- A Case Study. International Journal of Applied Agricultural Research., 4 (3):203-214

Kumar, A. and G. N. Tiwari (2006). Effect of shape and size on convective mass transfer coefficient during greenhouse drying (GHD) of jaggery. Journal of Food Engineering, 73(2): 121-134.

Lamdande, A. G.; S. T.Khabeer; R. Kulathooran and I. Dasappa (2018). Effect of replacement of sugar with jaggery on pasting properties of wheat flour, physico-sensory and storage characteristics of muffins. Journal of Food Science and Technology., 55 (8): 3144-3153

Mandal, D. ; S. Tudu ; S.R. Mitra and G.C. De (2006). Effect of common packing materials on keeping quality of sugarcane Jaggery during monsoon season. Sugar Tech., 8:137-142.

Manjare, A. and J. Hole (2016). Exhaust Heat Recovery of Jagger Making Furnace., International Journal of Science and Research (IJSR), 5(4): 165-170.

Manley, D. (2011). Manley's technology of biscuits, crackers and cookies. Elsevier, Woodhead Publishing, Oxford.

Sahu, A.P. and A.K. Saxena (1994). Enhanced translocation of particles from lungs by jaggery. Environ Health Perspect., 102:211-214.

Sahu, A. P. and B. Paul (1998). The role of dietary whole sugar-jaggery in prevention of respiratory toxicity of air toxics and in lung cancer. Toxicology Letters, 95(1): 154.

Singh, M. ; K.M. Bharadwaj and M.L. Agrawal (1978) Storage of jaggery. Co-oper Sugar., 3:14-17.

Snedecor, G. A. and W. G. Cochran (1976). Statistical Method. Iowa State Univ. Press, Ames.

SPSS 10.0 for Windows Student Version CD-ROM - March 21, 2000 
USDA (US Department of Agriculture),( 2014). National Nutrient Database for Standard Reference, Release 26, Basic report 19335, Sugars, granulated. Retrieved from www.ars.usda.gov/nuttientdata/sr.

Van Der Sman, R.G.M. and S. Renzetti (2018). Understanding functionality of sucrose in biscuits for reformulation purposes. Critical Reviews in Food Science and Nutrition., 59(1):1-15

Wondimu, A. and N.G. Malleshi (1996). Development of weaning foods based on malted, popped, and roller-dried barley and chickpea. The United Nations University Press Food and Nutrition Bulletin. 17(2):169-176.

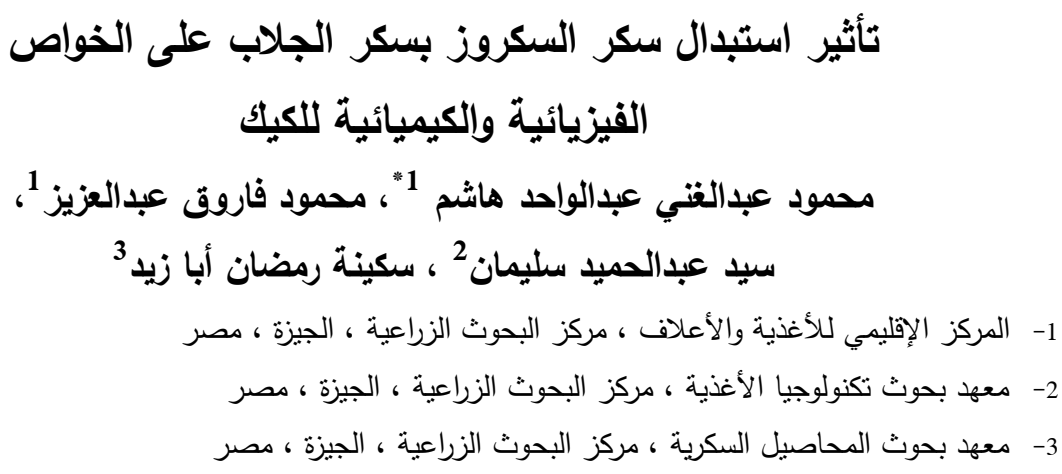

يعتبر السكر الجلاب Jaggery (Gur) من المحليات الطبيعية التي يتم إنتاجها بتركيز

عصير قصب السكر بما يحتويه من عناصر معدنية وفيتامينات. وقد استخدم في هذا البحث

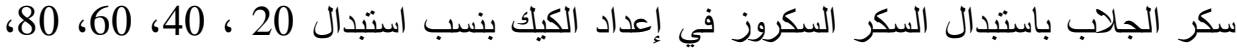

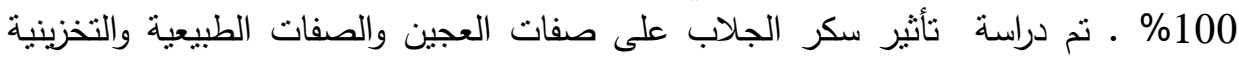

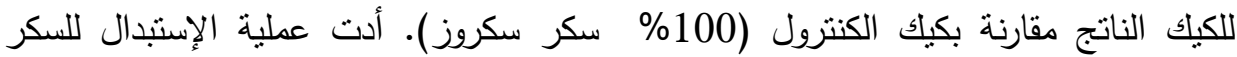

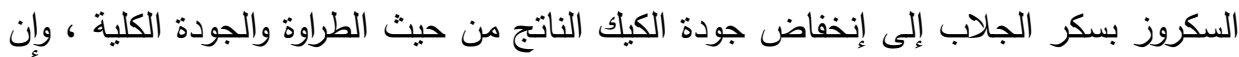

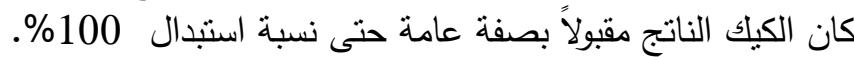
أظهرت دراسة الحمل الميكروبي ( خاصة بكتيريا القولون والسالمونيلا) سلامة الكيك الناتج

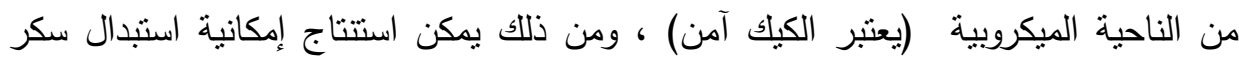
الجلاب بالسكر السكروز دون تأثثرات غير مرغوبة العنى على المنتج. 